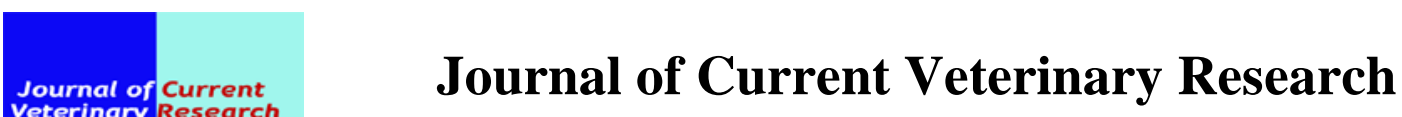

ISSN:4026-2636

Journal homepage: http://www.jcvr.journals.ekb.eg

\title{
Bacteriological and Molecular Studies on Virulence Encoding Genes in Escherichia coli Isolated from Diseased Ducks
}

Youmna El-Shabrawy ${ }^{1}$, Reda Tarabees ${ }^{1 *}$, Alaa Eldeen Hussien ${ }^{1}$, Ashraf Awad ${ }^{2}$

${ }^{1}$ Department of Bacteriology, Mycology and Immunology Faculty of Veterinary Medicine, University of Sadat City, Egypt

${ }^{2}$ Department of Bacteriology, Faculty of Veterinary Medicine, Benha University, Benha, Qalioubeya, Egypt

*Corresponding Author: reda.tarabees@vet.usc.edu.egＳubmitted: 17 Nov. 2018

Accepted: 31 Dec. 2018

\section{ABSTRACT}

Avian colibacillosis is considered a major bacterial disease in the poultry industry worldwide and one of the most common avian diseases that communicable to human. A prevalence study on APEC was carried out on 56 cloacal swabs isolated from 17 weeks old ducks suffering from diarrhea. The isolates were cultured onto MacConkey and EMB agar for isolation and identification of $E$. coli followed by serotyping then PCR for the detection of virulence encoding genes (iss, fimH, eaeA, tsh, ibeA, stx 1 and stx2) and their phylogenetic group. The collected data showed that, out of 56 isolates 12 isolates were typical APEC commonly belong to7 different serogroups and having at least two virulence genes. The data demonstrated that, iss and fimH encoding genes were present in all the examined serogroups (100\%). In contrast stx 1 and eaeA were absent in all isolates, while tsh and ibeA were variable $(63.63 \%, 27.27 \%)$, respectively. The presented phylogenetic groups were A and B1 in percentage of $27.27 \%$ and $72.72 \%$, respectively. The use of phylogenetic groups makes a revolution in the identification of APEC which enhanced our knowledge for APEC pathogenicity and helping pave the road for the application of the suitable preventive and curative measures in order to reduce the economic drawbacks of avian colibacillosis in large-scale farms.

Keywords: E. coli, Virulence genes, Phylogenetic grouping, Ducks

\section{INTRODUCTION}

Escherichia coli is distributed normal inhabitant of the gastrointestinal tract of humans, poultry and animals. It is a nonsporulating rod-shaped, Gram-negative, a facultatively anaerobic bacterium. The optimal growth temreature of most $\mathrm{E}$. coli strains is $37^{\circ} \mathrm{C}$ and some exceptional strains can grow at temperatures up to $49^{\circ} \mathrm{C}$ (Tenaillon et al., 2010).

Colibacillosis, caused by avian pathogenic E. coli (APEC) is the most common bacterial infection of all ages of commercial ducks with serious economic losses due to the high morbidity and mortality. Infection with APEC is mainly via the respiratory tract and air sacs and is usually secondary to infection by Mycoplasma or a virus. The disease has two main forms, acute and chronic. The acute form is characterized by the congested carcass, congested lungs and small hemorrhages of the heart and air sacs. While, in case of chronic infections the main signs are pericarditis, perihepatitis, enlargement of the liver, airsacculitis and pneumonia (Johnson et al., 2007).

Colibacillosis is one of the most common avian diseases that posed potential hazards to the public health (Kabir et al., 2017). A number of strains possess certain genes making them pathogenic which associated with intestinal (IPEC) and extraintestinal (ExPEC). The intestinal pathogenic groups includes enterotoxigenic E. coli (ETEC), enteropathogenic $E$. coli (EPEC), enterohemorrhagic E. coli (EHEC), enteroinvasive $E$. coli (EIEC), enteroaggregative $E$. coli (EAEC), diffusely adherent E. coli (DAEC) (Logue et al., 2017), while the extra-intestinal $E$. coli it is known that APEC infecting poultry, UPEC infecting humans and animals, and NMEC infecting infants, share common phylogenetic origins (Moulin et al., 2006; Johnson et al., 2006 \& Ewers et al., 2007).

The pathogenesis of APEC infections comprises four stages; colonization of the 
respiratory tract, crossing of the epithelium and penetration into the mucosa of the respiratory organs (air sacs), survival and multiplication in the bloodstream and in the internal organs, production of deleterious effects on the eukaryotic cells and tissues leading to lesions followed by the clinical signs (Dho-Moulin and Fairbrother, 1999). The serotyping analysis was recommended as a more specific identification approach that aims to classify the pathogenic strains based on their surface antigens, which divided into serogroups and serotypes on basis of their antigenic composition (somatic or $\mathrm{O}$ antigens for serogroups and flagella or $\mathrm{H}$ antigens for serotypes). Many strains express a third class of antigens (capsular or $\mathrm{K}$ antigens) (Compos et al., 2004).

E. coli isolated from clinical cases of colibacillosis were shown to have different combinations of virulence genes (Ewers et al., 2005). However, in some E. coli possess virulence genes in combinations not known to be associated with disease and may be considered as potentially pathogenic (Nicholson et al., 2016 and Logue et al., 2017). Recently, the use of phylogenetic groups makes a revolution in the identification of APEC, which enhanced our knowledge for APEC pathogenicity aiming to evaluate the possibility of these $E$. coli strains as predictors for future hazard zoonotic diseased. In addition, the role of phylogenetic type in APEC examines to assess the association between virulence gene carriage and phylogenetic type (Alizade et al., 2017). The species is divided into four groups (A, B1, B2, D) (Clermont et al., 2000). The commensal strains belong to groups (A and B1), whilst ExPEC strains frequently belong to phylogroups (B2 and D) and the intestinal pathogenic strains belonging to groups (A, B1 and D). Addition of new subgroups those were the groups A1, B3 (only found in humans) and D2 (Carlos et al., 2010) which were determined by presence and/or absence of the three genetic markers, chuA, yjaA, and TSPE4.C2 by a triplex PCR: chuA, a gene associated with heme transport in (EHEC); yjaA, a gene of unknown function and an anonymous DNA fragment called TSPE4.C2 that was identified as a putative lipase esterase gene (Gordon et al., 2008).

The present study was aimed to isolate and identify the most common serogroups of $E$. coli associated with diarrhea in ducks. In addition, the isolates were further examined for the presence of some virulence encoding genes using specific primer sets.

\section{MATERIALS AND METHODS}

\section{Samples and samples preparation}

A total of 56 cloacal swabs were collected from 16- and 17-weeks old ducks at Behera Governorate, then transferred immediately under full aseptic conditions for bacteriological isolation and identification.

\section{Isolation and identification of $\boldsymbol{E}$. coli}

The samples were cultured on the MacConkey agar plate for 24hrs. The typical colony characteristic of $E$. coli where it appeared as a rose pink colony on MacConkey agar medium, then the suspected colony cultured on EMB media the typical colony gave the characteristic metallic sheen appearance. The isolates were further identified based on the biochemical tests and the serology using $\mathrm{O}$ and $\mathrm{H}$ antigens according to Kok et al., (1996) by using rapid diagnostic E. coli antisera sets (DENKA SEIKEN Co., Japan) for diagnosis of the Enteropathogenic types. slide agglutination tests were performed with the diagnostic sera to identify the O-antigen.

\section{pathogenicity test}

Congo red is a simple dye that can be readily incorporated into an agar gel media. Congo red positive $(\mathrm{CR}+)$ E. coli colonies are dark red due to binding of the dye and also demonstrate wrinkling of the colony surface, E. coli colonies that do not bind the dye (CR-) demonstrate a smooth white colonial morphology (Vinal, 1986).

\section{Extraction of bacterial DNA}

DNA extraction was carried out from pure strains of E. coli cultured on nutrient broth and incubated overnight using The QIAamp DNA Mini Kit Multiplex Polymerase chain reaction (PCR) for the detection of E.coli.

Multiplex PCR reaction was performed from the positive isolates. The reaction mixture was made containing $1 \mu \mathrm{l}$ DNA template, $0.5 \mu \mathrm{M}$ of each primer, $25 \mu \mathrm{L}$ of $2 \mathrm{x}$ multiplex master mix (Takara) and the final volume was adjusted to $50 \mu \mathrm{L}$ with PCR water. To obtain the amplicon 35 cycles of denaturation at $94^{\circ} \mathrm{C}$ for $30 \mathrm{~s}, 55^{\circ} \mathrm{C}$ for $30 \mathrm{~s}$, and annealing at $72^{\circ} \mathrm{C}$ for $2 \mathrm{~min}$ and a final extension at $72^{\circ} \mathrm{C}$ for 10 
min. The amplified products were then resolved by electrophoresis in $2 \%$ agarose gel at $100 \mathrm{~V}$

solution and documentation was done using the Gel Doc system. The primers used are mentioned in Table 1.

PCR amplification of virulence genes and phylogenetic groups

PCR amplification of seven virulence genes and three genes of phylogenetic groups using specific primers for all $E$. coli isolates as showed in table (1). The reaction mixture was for $60 \mathrm{~min}$. Gels were stained with ethidium bromide

made containing $1 \mu \mathrm{l}$ DNA template, $0.5 \mu \mathrm{M}$ of each primer, $25 \mu \mathrm{L}$ of $2 \mathrm{x}$ multiplex master mix (Takara) and the final volume was adjusted to $50 \mu \mathrm{L}$ with PCR water. The isolates were amplified individually for the four genes using specific primers with, 35 cycles of initial denaturation $95^{\circ} \mathrm{C} 3 \mathrm{~m}$, denaturation $95^{\circ} \mathrm{C}$ for $30 \mathrm{sec}$, annealing at $55^{\circ} \mathrm{C}$ for $30 \mathrm{sec}$, extension at $72^{\circ} \mathrm{C}$ for $1.2 \mathrm{~m}$ and a final extension at $72^{\circ} \mathrm{C}$ for $7 \mathrm{~m}$.

Table (1): Oligonucleotide primers sequences

\begin{tabular}{|c|c|c|c|}
\hline Gene & $\begin{array}{c}\text { Primer Sequence } \\
\text { 5'-3' }\end{array}$ & $\begin{array}{l}\text { Amplified } \\
\text { product }\end{array}$ & Refrances \\
\hline \multirow{2}{*}{ stx1 } & ACACTGGATGATCTCAGTGG & 614 bp & \multirow{4}{*}{ Dipineto et al., 2006} \\
\hline & CTGAАTCССССТССАТТАТG & & \\
\hline \multirow{2}{*}{ stx 2} & CCATGACAACGGACAGCAGTT & \multirow{2}{*}{779 bp } & \\
\hline & CCTGTCAACTGAGCAGCACTTTG & & \\
\hline \multirow{2}{*}{$\operatorname{chuA}$} & GAC GAA CCA ACG GTC AGG AT & \multirow{2}{*}{279 bp } & \multirow{6}{*}{ Jeong et al., } \\
\hline & TGC CGC CAG TAC CAA AGA CA & & \\
\hline \multirow{2}{*}{ yјаA } & TGA AGT GTC AGG AGA YGC TG & \multirow{2}{*}{211 bp } & \\
\hline & ATG RAG AAT GCG TTC CTC AAC & & \\
\hline \multirow{2}{*}{ tspE4C2 } & GAG TAA TGT CGG GGC ATT CA & \multirow{2}{*}{152 bp } & \\
\hline & CGC GYC AAC AAA GTA TTR CG & & \\
\hline \multirow{2}{*}{ fimH } & TGCAGAACGGATAAGCCGTGG & \multirow{2}{*}{508 bp } & \multirow{2}{*}{$\begin{array}{l}\text { Ghanbarpour and } \\
\text { Salehi, } 2010\end{array}$} \\
\hline & GCAGTCACCTGCCCTCCGGTA & & \\
\hline Tsh & $\begin{array}{l}\text { GGT GGT GCA CTG GAG TGG } \\
\text { AGT CCA GCG TGA TAG TGG }\end{array}$ & 620 bp & Delicato et al., 2003 \\
\hline eaeA & $\begin{array}{l}\text { ATG CTT AGT GCT GGT TTA GG } \\
\text { GCC TTC ATC ATT TCG CTT TC }\end{array}$ & 248 bp & Bisi-Johnson et al., 2011 \\
\hline \multirow{2}{*}{ Iss } & ATGTTATTTTCTGCCGCTCTG & \multirow{2}{*}{266 bp } & \multirow{2}{*}{ Yaguchi et al., 2007} \\
\hline & CTATTGTGAGCAATATACCC & & \\
\hline$i b e A$ & $\begin{array}{l}\text { TGGAACCCGCTCGTAATATAC } \\
\text { CTGCCTGTTCAAGCATTGCA }\end{array}$ & 342 bp & Ewers et al., 2007 \\
\hline
\end{tabular}

Table (16): The prevalence of the virulence genes among isolated E. coli strains using PCR.

\begin{tabular}{cccccccccccc}
\hline Genes & eaeA & fimH & tsh & iss & ibeA & Stx1 & Stx2 & chuA & yjaA & tspE4.C2 & $\begin{array}{c}\text { Strain } \\
\text { characterization }\end{array}$ \\
\hline O2 & - & + & + & + & - & ND & ND & - & - & - & EPEC \\
O26 & - & + & + & + & + & ND & ND & - & - & + & EHEC \\
O128 & - & + & + & + & - & - & - & - & - & + & ETEC \\
O158 & ND & ND & ND & ND & ND & ND & ND & ND & ND & ND & EPEC \\
O2 & - & + & - & + & - & ND & ND & - & - & + & EPEC \\
O78 & - & + & - & + & - & ND & ND & - & - & - & EPEC \\
O91 & - & + & + & + & - & - & + & - & - & + & EHEC \\
O91 & - & + & + & + & + & - & - & - & - & + & EHEC \\
O78 & - & + & + & + & + & - & - & - & - & - & EPEC \\
O78 & - & + & - & + & - & ND & ND & - & - & + & EPEC \\
O91 & - & + & - & + & - & - & - & - & - & + & EPEC \\
Total & 0 & 11 & 7 & 11 & 4 & 0 & 1 & 0 & 0 & 8 & EHEC \\
Positive & & + & + & - & ND & ND & - & - & + & \\
\hline
\end{tabular}

Positive: $+\quad$ Negative: - $\quad$ Not done: ND 


\section{Results and Discussion}

The presented data in table 2 showed that, E. coli was recovered from 12/56 cloacal samples collected from 16 and 17 weeks of diseased ducks with diarrhea (reddish, whitish and yellowish diarrhea) in a percentage of $21.52 \%$. This outcome is higher compared to that previously obtained by (Amin et al., 2013) and similar to obtained by (Shaaban, 2015), this result is lower compared to that obtained by (Moemen et al., 2014 and Saviolli et al., 2016) who isolated E. coli form $92.6 \%$ and $86.8 \%$ of the examined samples, respectively. The confirmed strains belonged to 7 different serogroups (O91, O113, O78, O2, O158, O128 and O26). The predominant serogroups in duck isolated from cloacal swabs were O78, O91 and O2 in a percentage of (25\%, 25\% and $16.67 \%$ ), respectively. These outcomes are consistent with the findings previously obtained by (Huja et al., 2015) who reported that serotype O78 was the major cause of avian colisepticemia. In addition (Ewers et al., 2007; Asway et al., 2008; Aaron et al., 2012 and Nolan et al., 2013) noticed that (O2 and O78) serogroups were the predominantly isolated serogroups. Also, O113:H4 has identified herein a similar finding to that previously showed by (Monaghan et al., 2011 and Feng et al., 2017) who recognized O113:H4 as a major public health concern. Moreover, O26 was successfully identified from the cloacal swabs collected from 17-weeks-old diseased ducks; this outcome is similar to that obtained by (Paddock et al., 2012; Amin et al., 2013 and shaaban, 2015). In contrast, this result is inconsistent with the findings of (Torky et al., 1995 and Marwah et al.,2010) who recorded these serogroups are not common in chickens and ducks but may be transmitted from other animals to chickens raised near to these animals. Also, $\mathrm{O} 158$ and O128:H2 were successfully identified as similar to (shaaban., 2015). O91: H21 was successfully recovered from the cloacal swabs of diseased ducks and this serotype is considered as (EHEC). These results agreed with (Neher et al., 2016). Different serotypes were previously reported in different studies which similar to our results O91, O78 and O2, and serotypes O113, O128, O26, O91 were previously obtained in the study carried out by ( Cordoni et al., 2016 and Son et al., 2014) respectively. On the other hand (Beutin et al., 1993) isolated O91: H- and O128: H2 from animal species.

In the present study, Examination of the pathogenicity of the confirmed isolates using congo red pathogenicity test showed that nearly $72 \%$ of the isolates were positive. This outcome is agreed with (El-ashker, 2006) who reported that $(70 \%)$ of $\mathrm{E}$. coli isolated from poultry were Congo red positive and disagreed with (Hassan ,2009) who reported that Congo red positive rate of.(\%)...)

The stx 1 gene not amplified in all examined serogroups. These outcomes are consistent with the findings previously obtained by (Shaaban., 2015) and inconsistent with the findings of (Farooq et al., 2009 and Johura et al., 2017). Also, stx2 gene was not amplified in serogroups (O113, O128 and two different isolates of 091). These outcomes are consistent with the findings previously obtained by (Shimaa, 2013 and Shaaban, 2015). The stx2 was successfully amplified in one isolate of serogroup O91. This result is similar to (Farooq et al., 2009; Son et al.,2014; Yousef et al., 2015; Neher et al., 2016 and Johura et al., 2017) .

The eaeA gene was not amplified in all serogroups. This outcome came in accordance with that previously obtained by (Olsen and Christensen, 2011, and Shimaa, 2013) who found eaeA gene not detected in all APEC isolates, also our result is similar to (Feng et al., 2017) who detected O113:H4 not produce the intimin protein, meanwhile these outcomes inconsistence with previously obtained by (Farooq et al., 2009; Yousef et al., 2015; Son et al.,2014; Neher et al., 2016 and Bai et al., 2016) who found eaeA gene detected in APEC isolates .

The fimH gene was successfully amplified in all examined serogroups giving a positive PCR product of $508 \mathrm{bp}$. These outcomes came in accordance with the finding previously recorded by (Maciel et al., 2016; Saviolli et al.,2016 and Alizade et al.,2017). Also, the tsh gene was successfully amplified in examined E. coli serogroups. These outcomes go in parallel with those obtained (Qabajah and Yaquoub, 2010). In contrast, it higher compared to that previously obtained by (Shaaban., 2015) who found tsh in four strains in ducks . 
The successfully amplified of iss (increase serum survival) in all examined serogroups was consistent with those finding previously by (Johnson et al., 2008; Qabajah and Yaqoub, 2010; Jeong et al., 2011and Shaaban 2015) who stated that iss gene is the most important and widely distributed virulence marker of APEC. The ibeA (invasion of brain endothelium protein $\mathrm{A}$ ) is a virulence factor found in newborn meningitis and avian pathogenic strains. The ibeA gene was successfully amplified in (O113, O26 and one isolates of O91). This outcome is higher compared to that previously obtained by (Wang et al., 2010) who found ibeA gene in a percentage of $(10.6 \%)$ of APEC isolates and was not found in healthy ducks. In addition, these outcomes go in parallel with those previously obtained by (Saviolli et al., 2016) who detected ibeA in APEC. The highest amount of E. coli strains (72.72\%) belong to group B1, followed by group A (27.27\%). These outcomes are consistent with the findings previously obtained by (Walk et al., 2007, Carlos et al., 2010, Logue et al., 2017 and Alizade et al., 2017) and lower compared to that obtained by (Carlos et al., 2010) who found that group B1 was (100\%) among all the analyzed hosts followed by group A was (83.3\%). Of note, the majority of E. coli strains that are able to persist in the environment belong to the B1 phylogenetic group (Walk et al., 2007).The successfully amplified of iss (increase serum survival) in all examined serogroups was consistent with those finding previously by (Johnson et al., 2008; Qabajah and Yaqoub, 2010; Jeong et al., 2011and Shaaban 2015) who stated that iss gene is the most important and widely distributed virulence marker of APEC. The ibeA (invasion of brain endothelium protein $A$ ) is a virulence factor found in newborn meningitis and avian pathogenic strains. The ibeA gene was successfully amplified in (O113, O26 and one isolates of O91). This outcome is higher compared to that previously obtained by (Wang et al., 2010) who found ibeA gene in a percentage of $(10.6 \%)$ of APEC isolates and was not found in healthy ducks. In addition, these outcomes go in parallel with those previously obtained by (Saviolli et al., 2016) who detected ibeA in APEC. The highest amount of E. coli strains (72.72\%) belong to group B1, followed by group A (27.27\%). These outcomes are consistent with the findings previously obtained by (Walk et al., 2007, Carlos et al., 2010, Logue et al., 2017 and Alizade et al., 2017) and lower compared to that obtained by (Carlos et al., 2010) who found that group B1 was (100\%) among all the analyzed hosts followed by group A was (83.3\%). Of note, the majority of E. coli strains that are able to persist in the environment belong to the B1 phylogenetic group (Walk et al., 2007).

\section{CONCLUSION}

The better understanding of the pathogenesis of $E$. coli induced colibacillosis in ducks will potentially minimize the economic drawbacks of such this infection. The introducing of modern techniques such as PCR significantly improved our knowledge about E. coli induced colibacillosis in ducks.

\section{REFRENCES}

Alizade, H.1,2*, Ghanbarpour, R. 3,4, Jajarami, M.3, Askari, A. 2017. Phylogenetic typing and molecular detection of virulence factors of avian pathogenic Escherichia coli isolated from colibacillosis cases in Japanese quail. Veterinary Research Forum. 8 (1) 55 - 58

Asawy, A. M. E.; El-Latif, M. M. A. (2010): Some bacteriological and serological studies on enteritis in ducks. Assiut Veterinary Medical Journal; 56(125):239-249. 33 ref.

Aaron, M. L.; Subhashinie ,K.W., Timothy J. J., Sara J. J., Avanti S. S., Dorie K. L., Harley W. M., Dianna M. J., Catherine M. L., Steven L. F., and Lisa K. N. (2012): Recombinant iss as a Potential Vaccine for Avian colibacillosis. Avian Diseases: March 2012, Vol. 56, No. 1, pp. 192-199.

Amin, M. A.; Ali, M. N., Awadallah, M. A., Ahmed, H. A.; Gharieb, R. M. A., Abu-El-Ezz, R. M., Mohamad, R. E. (2013.): Prevalence of Enterobacteriacea in wild birds and humans at Sharkia Province; with special reference to the genetic relationship between $\mathrm{E}$. coli and Salmonella isolates determined by protein profile analysis. The Journal of American Science; 9(4):173-183. 67 ref.

BEUTIN, L. GEIER, D1., STEINRUCK, H,1., ZIMMERMANN, S. (1993): Prevalence and Some Properties of Verotoxin (Shiga-Like Toxin)-Producing Escherichia coli in Seven Different Species of Healthy Domestic Animals. JOURNAL OF CLINICAL 
MICROBIOLOGY., p. 2483-2488 Vol. 31, No. 9

Bisi-Johnson, M.A.; Obi, C.L.; Vasaikar, S.D.;

Baba, K.A. and Hattori, T. (2011): Molecular basis of virulence in clinical isolates of Escherichia coli and Salmonella species from a tertiary hospital in the Eastern Cape, South Africa. Gut Pathogens 2011, 3:9.

Bai X, Hu B, Xu Y, Sun H, Zhao A, Ba P, Fu S, Fan R, Jin Y, Wang H, Guo Q, Xu X, Lu S and Xiong Y (2016) Molecular and Phylogenetic Characterization of Non-O157 Shiga ToxinProducing Escherichia coli Strains in China. Front. Cell. Infect. Microbiol. 6:143.

Compos, L. C.; Franzolin, M. R. and Trabuls, L.R. (2004): Diarrheagenic E. coli categories among the traditional entero pathogenic E. coli O-serogroups Mem. Inst. Oswald Cruz; 99 (6):545-552.

Cordoni, G 1., Woodward, M 2, Wu, H 3., Alanazi1, M, Wallis, T.,4 and Roberto M. La Ragione1. (2016). Comparative genomics of European avian pathogenic E. coli (APEC) Cordoni et al. BMC Genomics. 17:960

Clermont, O., Bonacorsi, S., and Bingen, E. (2000). Rapid and simple determination of the Escherichia coli phylogenetic group. Appl. Environ. Microbiol. 66, 4555-4558.

Avian pathogenic Dho-Moulin, M., and Fairbrother, J. M. (1999). Escherichia coli (APEC). Vet.Res.30,299-316.

Carlos, C., Pires, M. M., Stoppe, N. C., Hachich, E. M., Sato, M. I., Gomes,T. A., et al. (2010). Escherichia coli phylogenetic group determination andits application in the identification of the major animal source of fecal contamination. BMC Microbiol. 10:161.

Dipineto, L.; Santaniello, A.; Fontanella, M.; Lagos, K.; Fioretti, A. and Menna, L.F. (2006). Presence of Shiga toxin-producing Escherichia coli O157:H7 in living layer hens. Letters in Applied Microbiology 43 (2006) 293-295.

Delicato, E.R.; de Brito, B.G.; Gaziri, L.C.J. and Vidotto, M.C. (2003): Virulence-associated genes in Escherichia coli isolates from poultry with colibacillosis. Veterinary Microbiology 94 (2003) 97-103.

Dho-Moulin, M., and Fairbrother, J. M. (1999). Avian pathogenic Escherichia coli (APEC).Vet.Res.30,299-316.
Ewers, C., G. Li, H. Wilking, S. Kiessling, K. Alt, E.-M. Antão, C. Laturnus, I. Diehl, S. Glodde, T. Homeier, U. Boehnke, H. Steinrueck, H.C.Philipp, and L. H. Wieler. 2007. Avian pathogenic, uropathogenic, and newborn meningitis-causing Escherichia coli: How closely related are they? Int. J. Med. Microbiol. 297:163-176.

EL-ashker, H. M. (2006): Correlation between antigenic structure of $E$. coli and its virulence. Ph. V. Sc., Thesis (Microbiology), Fac. Vet.Med. Cairo Univ.

Ewers, C.; Janssen, T., Kiessling, S., Philipp, H. C. and Wieler, L. H. (2005): Rapid detection of virulence-associated genes in avian pathogenic E. coli by multiplex polymerase chain reaction. Avian Dis., 49 (2): 269-273.

Feng P, Delannoy S, Lacher DW, Bosilevac JM, Fach P. (2017): Characterization and Virulence Potential of Serogroup O113 Shiga Toxin-Producing Escherichia coli Strains Isolated from Beef and Cattle in the United States. J Food Prot. ;80(3):383-391.

Farooq, S.; Hussain, I., Mir, M. A., Bhat, M. A., Wani, S. A. (2009): Isolation of atypical enteropathogenic $E$. coli and Shiga toxin 1 and 2f-producing $E$. coli from avian species in India. Letters in Applied Microbiology. 48(6):692-697. 27.

Ghanbarpour and Salehi (2010): Determination of Adhesin Encoding Genes in Escherichia coli Isolates from Omphalitis of Chicks. American Journal of Animal and Veterinary Sciences 5 (2): 91-96, 2010

Gordon, D. M., Clermont, O., Tolley, H., and Denamur, E. (2008). Assigning Escherichia coli strains to phylogenetic groups: multilocus sequence typing versus the PCR triplex method. Environ.Microbiol. 10, 2484-2496.

Huja S, Oren Y, Trost E, Brzuszkiewicz E, Biran D, Blom J, Goesmann A, Gottschalk G, Hacker J, Ron EZ, Dobrindt U. 2015. Genomic avenue to avian colisepticemia. MBio. 13;6(1).

Johnson, T. J.; Kariyawasam, S., Wannemuehler, Y., Mangiamele, P.,Johnson And Nolan, L. K. (2007): The Genome Sequence Of Avian Pathogenic E.coliStrain O1:K1:H7 Shares Strong Similarities With Human Extraintestinal Pathogenic E. Coli Genomes. $J$ Bacteriol, 189, 3228-36. 
Jeong, Y.W.; Kim T.E.; Kim, J.H.; Kwon, H.J. (2012): Pathotyping avian pathogenic Escherichia coli strains in Korea. J Vet Sci. 2012 Jun;13(2):145-52.

Johnson, J. R., M. A. Kuskowski, M. Menard, A. Gajewski, M. Xercavins, and J. Garau. 2006. Similarity between human and chicken Escherichia coli isolates in relation to ciprofloxacin resistance status. J. Infect. Dis. 194:71-78

Johura FT, Parveen R, Islam A, Sadique A, Rahim MN, Monira S, Khan AR, Ahsan S, Ohnishi $\mathrm{M}$, Watanabe H, Chakraborty S, George CM, Cravioto A, Navarro A, Hasan B and Alam M (2017) Occurrence of Hybrid Escherichia coli Strains Carrying Shiga Toxin and Heat-Stable Toxin in Livestock of Bangladesh. Front. Public Health 4:287.

Kok, T.; Worswich, D. and Gowans, E. (1996): Some serological techniques for microbial and viral infections. In Practical Medical Microbiology (Collee, J.; Fraser, A.; Marmion, B. and Simmons, A., eds.), $14^{\text {th }}$ ed., Edinburgh, Churchill Livingstone, UK.

Kabir, L, S. M. 2017 “Avian Colibacillosis and Salmonellosis: A Closer Look at Epidemiology, Pathogenesis, Diagnosis, Control and Public Health Concerns.” International Journal of Environmental Research and Public Health 7.1: 89-114.

Logue CM, Wannemuehler Y, Nicholson BA, Doetkott C, Barbieri NL and Nolan LK (2017) Comparative Analysis of phylogenetic Assignment of Human and Avian ExPEC and Fecal Commensal Escherichia coli Using the (Previous and Revised) Clermont

Phylogenetic Typing Methods and its Impact on Avian Pathogenic Escherichia coli (APEC) Classification. Microbiol. 8:283.

Maciel $\mathrm{JF}^{1}$, Matter $\mathrm{LB}^{2}$, Trindade $\mathrm{MM}^{1}$, Camillo $\mathrm{G}^{1}$, Lovato $\mathrm{M}^{1}$, de Ávila Botton $\mathrm{S}^{1}$, Castagna de Vargas $\mathrm{A}^{3}$.Virulence factors and antimicrobial susceptibility profile of extraintestinal Escherichia coli isolated from an avian colisepticemia outbreak. Microb Pathog. 2017 Feb;103:119-122.

Mbanga $\mathrm{J}^{1}$, Nyararai YO.(2015) Virulence gene profiles of avian pathogenic Escherichia coli isolated from chickens with colibacillosis in Bulawayo, Zimbabwe. Onderstepoort J Vet Res. 2015 Apr 7;82(1):850.
Marwah, M. R.; Mohammad, E. E. and Mervat, S. H. (2010): Relationship between o-serogroup virulence and plasmid profile in E. coli isolated from diseased chickens. J. Food Safety: 30(3): 679-698.

Monaghan A, Byrne B, Fanning S, Sweeney T, McDowell D, Bolton DJ. Serotypes and virulence profiles of non-O157 Shiga toxinproducing Escherichia coli (STEC) from bovine farms. Appl Environ Microbiol 2011; 77:8662-8668.

Moemen A. Mohamed,1 Mostafa A. Shehata,1 and Elshimaa Rafeek(2014).Virulence Genes Content and Antimicrobial Resistance in Escherichia coli from Broiler Chickens. Hindawi Publishing Corporation Veterinary Medicine International Volume 2014, Article ID 195189, 6 pages.

Moulin-Schouleur, M., C. Schouler, P. Tailliez, M. R. Kao, A. Bree, P. Germon, E. Oswald, J. Mainil, M. Blanco, and J. Blanco. (2006). Common virulence factors and genetic relationships between O18:K1:H7 Escherichia coli isolates of human and avian origin. J. Clin. Microbiol. 44:3484-3492.

Nguyen, X.B.; Nguyen,V. C., Thi, M. K., Tran X.H., Thi,T.P., PhungDuy, H. H.( 2000): Investigation of Salmonella and E.coliinfections of ducks in Long An province, Vietnam Khoa Hoc KyThuat Thu Y (Veterinary Sciences and Techniques); 7(4):29-34.

Nolan, L. K., Barnes, H. J., Vaillancourt, J.-P., Abdul-Aziz, T., and Logue, C. M. (2013): Colibacillosis. Hoboken, NJ:Wiley-Blackwell.

Neher S, Hazarika AK, Barkalita LM, Borah P, Bora DP,Sharma RK (2016) Isolation and characterization of Shiga toxigenic Escherichia coli of animal and bird origin by multiplex polymerase chain reaction, Veterinary World 9(2): 123-127.

Olsen, M.S.C., Christensen, J.P. (2011): Clonality and virulence traits of E.coliassociated with haemorrhagic septicaemia. Avian Pathology, 40 (6): 587-595.

Paddock $Z^{1}$, Shi X, Bai J, Nagaraja TG. Vet Microbiol. 2012: Applicability of a multiplex PCR to detect O26, O45, O103, O111, O121, O145, and $\mathrm{O} 157$ serogroups of Escherichia coli in cattle feces. 4 ; 156(3-4):381-8. 
Qabajah, L.; Yaqoub, A. (2010): Identification and Screening of Avian Pathogenic E. coli Virulence Factors in Palestine. Biotechnology Research Center, Palestine Polytechnic University, P.O-Box 198, Hebron, Palestine

Shaaban,A.(2015): Molecular Characterization of E.Coli Isolated From Ducks. M.V.Sc. Thesis, Fac. Vet. Med., Sadat city Univ.

Shimaa, H.A.M. (2013): Some Advanced Studies on avian pathogenic E. coli in broiler chickens at Sharkia Governorate.M.V.Sc. Thesis, Fac. Vet. Med., Zagazig Univ.

Son I, Binet R, Maounounen-Laasri A, Lin A, Hammack TS, Kase +JA. Food Microbiol.(2014): Detection of five Shiga toxin-producing Escherichia coli genes with multiplex PCR. 40:31-40.

Saviolli JY, Cunha MPV, Guerra MFL, Irino, K, Catão-Dias JL, de Carvalho VM (2016) FreeRanging Frigates (Fregata magnificens) of the Southeast Coast of Brazil Harbor ExtraintestinalPathogenic Escherichia coli Resistant to Antimicrobials. PLoS ONE 11(2): e0148624.

Torky, H. A.; El-Nimr, M. M., Akeila M. A., Moussa, M. M.,Aly, A. , Band M. S. (1995): Isolation of E.coli from chickens. Alex. J. Vet. Sci. 11(4):577-585.

Tenaillon O, Skurnik D, Picard B, Denamur E. 2010. The population genetics of commensal Escherichia coli. Nat. Rev. Microbiol. 8:207217

Vinal, A.C. (1986): The association of Congo red binding and virulence in E. coli pathogenic for poultry Diss. Abstr. Int., 49 (6), 2059-2056.

Wang,C.P.; Wei, Q.A., Bao,G. L., Cui, Y.S., Liu, Y., Shao,Q.A., Xiao, C.W., Jian, L. (2010): Establishment of multiplex PCR assay for the diagnosis of Riemerellaanatipestifer and E.coliinfection in ducks. Chinese Journal of Veterinary Science; 30(3):352-355. 11 ref.

Walk ST, Alm EW, Calhoun LM, Mladonicky JM, Whittam TS. (2007): Genetic diversity and population structure of Escherichia coli isolated from freshwater beaches. Environ Microbiol.;9:2274-88.

Yaguchi, K.; Ogitani, T.; Osawa, R.; Kawano, M.; Kokumai, N.; Kaneshige, T.; Noro,T.;
Masubuchi, K. and Shimizu, Y.(2007): Virulence Factors of Avian Pathogenic Escherichia coli Strains Isolated from Chickens with Colisepticemia in Japan. Avian Dis. 51(3):656-62

Yousef, S. A; Ammar, A.M and Ahmed, D. A. (2015): Serological and Molecular Typing Of Avian Pathogenic E. coli Originated From Outbreaks Of Colibacillosis In Chicken Flocks.Vol: 4:2082-2088. 